\title{
Bioaccumulation of Polycyclic Aromatic Hydrocarbons and Mercury in Oysters (Crassostrea rhizophorae) from Two Brazilian Estuarine Zones
}

\author{
Ronaldo J. Torres, ${ }^{1}$ Augusto Cesar, ${ }^{2}$ Camilo D. S. Pereira, ${ }^{2}$ Rodrigo B. Choueri, ${ }^{2}$ \\ Denis M. S. Abessa, ${ }^{3}$ Marcos R. L. do Nascimento, ${ }^{4}$ Pedro S. Fadini, ${ }^{1}$ and Antonio A. Mozeto ${ }^{1}$ \\ ${ }^{1}$ Laboratório de Biogeoquímica Ambiental (LBGqA)-Núcleo de Estudos, Diagnósticos e Intervenções Ambientais (NEDIA), \\ Departamento de Química, UFSCar, Rod. Washington Luiz, 13565-905 São Carlos, SP, Brazil \\ ${ }^{2}$ Centro de Ciências do Mar e Meio Ambiente, Baixada Santista UNIFESP, Avenida Dona Costa, 95, 11060-001 Santos, SP, Brazil \\ ${ }^{3}$ Campus Experimental do Litoral Paulista, Universidade Estadual Paulista, Pça. Infante D. Henrique, s/no, 11330-900 São Vicente, \\ SP, Brazil \\ ${ }^{4}$ Laboratório de Poços de Caldas (LAPOC), CNEN, Comissão Nacional de Energia Nuclear, Rodovia Andradas, km 13, \\ 37701-970 Poços de Caldas, MG, Brazil
}

Correspondence should be addressed to Ronaldo J. Torres, rjtorres2000@yahoo.com.br

Received 18 April 2012; Revised 19 June 2012; Accepted 19 June 2012

Academic Editor: Roberto Danovaro

Copyright ( $) 2012$ Ronaldo J. Torres et al. This is an open access article distributed under the Creative Commons Attribution License, which permits unrestricted use, distribution, and reproduction in any medium, provided the original work is properly cited.

\begin{abstract}
Nowadays, organisms are increasingly being used in biomonitoring to assess bioavailability and bioaccumulation of contaminants. This approach can use both native and transplanted organisms in order to accomplish this task. In Brazil, most of the studies related to bioaccumulation of contaminants in oysters deal with metals. The present work employs this kind of test in Brazilian coastal estuaries (Santos and Paranaguá) to evaluate total mercury and polycyclic aromatic hydrocarbon contamination in sediments and oysters (native and caged Crassostrea rhizophorae). The methodologies employed were based on known USEPA methods. Results have shown a significant contamination in Santos sediments and consequent bioavailability of organisms. Paranaguá sediments presented lower contamination in sediments, but native oysters were able to accumulate total Hg. The experiments done with caged oysters did not show significant bioaccumulation of $\mathrm{Hg}$ and PAHs in the Paranaguá site, but proved to be an excellent tool to assess bioavailability in the Santos estuary since they were able to bioaccumulate up to $1,600 \%$ of total PAH in the samples from the inner part of this estuary when compared to control organisms. Multivariate statistical analyses employed to these results have separated the sites evaluated and the most contaminated samples from the least contaminated.
\end{abstract}

\section{Introduction}

Some organic and inorganic chemical contaminants have the capacity of persisting in the environment, bioaccumulate in tissues, and are toxic to organisms. The main classes of elements and compounds that belong to this category are some metals such as mercury, cadmium, and lead as well as those denominated POPs (persistent organic pollutants) such as pesticides, dioxins, polychlorinated biphenyls (PCBs), and polycyclic aromatic hydrocarbons (PAHs) [1,2].

Once in the environment, the contaminants interact with sediments, water column, and organisms; such interactions are controlled by several physical and chemical processes, and the final result may be the chemical release, immobilization, or their transformation into more reactive forms or subproducts, which are more effectively available to organisms [3]. Bioavailability is also governed by kinetics and partitioning of the contaminant in the environment [4].

Bioaccumulation is the process by which a chemical is absorbed by an organism exposed to it. It is a net result of competing processes of absorption, ingestion, digestion, and excretion [5] and involves also the endogenous processes of biological depuration. Bioaccumulation studies can also be interpreted in human health risk analysis when the target 
organisms are cultivated or used for human consumption. PAH bioaccumulation is dependent on fatty and lipid-rich tissues and organs [6].

Since the mid-1970s, environmental assessment programs have utilized bivalve mollusks as monitoring agents of chemical contaminants in marine areas [7]. Because of their sedentary habit and ability to bioaccumulate pollutants, mussels and oysters have been employed as sentinel organisms in environmental quality monitoring studies in coastal regions. The assessment of oysters and mussels as sentinel organisms has also been used in Brazil in recent years [8-11].

The estuarine systems of Santos and Paranaguá are major port areas in southeastern Brazil. Studies undergone in these areas identified contamination and the bioavailability of contaminants in water and sediments from these systems through chemical, toxicological, and ecological assessments, as consequences of anthropic activities in this region [12-15]. One particular study [16] has evidenced bioaccumulation of contaminants in fish, crustaceans, and mollusks from the Santos Estuarine System. However, the relationship between sediment contamination and bioaccumulation was not effectively assessed. Some of these previous studies have shown high levels of mercury and PAH, especially in the Santos estuary $[12,13,15,16]$.

The central hypothesis of this study is that a number of anthropic activities, namely, industrial and municipal effluents from the study area as well as the dredging process and ship movement across the estuaries, can contaminate the organisms that live in these regions with metals such as mercury and hydrocarbons. Chemical analysis of the sediments and native and caged organisms may give the answers for the possibility of bioaccumulation and the risks posed to humans if these organisms are ingested. Whole integration of the results can establish a synoptic application of the assessment of environmental contamination, toxicity, and bioaccumulation. Assessment of other chemicals will be held for future studies.

\section{Materials and Methods}

Paranaguá Estuarine System (PES) and Santos Estuarine System (SES) (Figures 1(a) and 1(b), resp.) are two of the most important port areas in Brazil. PES is influenced by the port and seasonal tourism in an almost untouched coastal area. SES has heavy industries in it (petrochemicals, metallurgy, and fertilizes among others) and a large urban concentration. Both areas comprise ecologically significant ecosystems, such as mangroves and Atlantic rain forest; in addition, artisanal fisheries and familiar aquaculture activities are performed in many places all over the PES. Whilst for SES there is vast information on sediment contamination $[15,16]$, sediment toxicity $[17,18]$, and benthic communities' alterations [12], for PES little information about sediment contamination, toxicity, or benthic communities is available [14].

In both estuaries, four sampling stations were chosen (Figures 1(a) and 1(b)) in which sediment was collected through a van Veen dredge. Native oysters (Crassostrea rhizophorae) (Guilding, 1828) (Bivalvia: Ostreidae) were collected where possible, and one cage containing about 30 oysters from the same species (purchased from a farm in a reference area located in Guaratuba bay, about $40 \mathrm{~km}$ southwards PES) was placed at each point for bioaccumulation assessment. The sediments and native oysters were placed in plastic bags for analysis of mercury and in aluminum containers for PAH quantification, and they were kept frozen $\left(-20^{\circ} \mathrm{C}\right)$ prior to analysis. Two distinct periods were chosen for these experiments which were a dry season (August 2008) and a rainy season (May 2009). All samplings, handlings and storage of the sediments and organisms were conducted according to USEPA guidance [19].

After 30 days of exposure, the oysters were removed from the cage and transported to laboratory where the soft tissues were detached from the shells and placed in plastic bags or aluminum containers and finally frozen prior to laboratory analysis for $\mathrm{Hg}$ and $\mathrm{PAH}$.

For the analysis of $\mathrm{Hg}$, the sediment was dried in the oven at $60^{\circ} \mathrm{C}$ for 24 hours and grounded and homogenized. Soft tissues were digested in natura and part of them was dried for moisture content since results are usually expressed in dry weight. All laboratory analyses followed methods 245.5 and 245.6 from [19] where the sample is weighted and digested with a mixture of nitric and sulfuric acids, potassium permanganate, potassium persulfate with heating, and hydroxylamine hydrochloride, and stannous chloride was added prior to instrumental analysis by cold vapor atomic absorption spectrophotometry (CV-AAS-Varian, FS220). Quantitation limit was $0.2 \mu \mathrm{g} \mathrm{kg}^{-1}$ for both sediments and organisms.

Sixteen priority PAH listed by USEPA [20] were extracted in both sediments and oysters according to method 3550b [21]. The individual compounds analyzed are naphthalene, acenaphthylene, acenaphthene, fluorene, phenanthrene, anthracene, fluoranthene, pyrene, benzo[a] anthracene, chrysene, benzo[b]fluoranthene, benzo[k]fluoranthene, benzo[a] pyrene, indeno[1,2,3-cd]pyrene, dibenzo[a,h]anthracene, and benzo[ghi]perylene. In this method, parts of the sediments and tissues were dried to obtain moisture content and other parts were digested in natura by ultrasound extraction with a mixture of hexane/acetone. The extract was submitted to a clean-up process in a glass column with silica gel and alumina eluted with a mixture of dichloromethane/hexane. Instrumental determination was done according to method $8270[19,21]$ by gas chromatography coupled to a mass spectrometer by Shimadzu, model QP2010. Quantitation limits have been established in the range from $0.081 \mu \mathrm{g} \mathrm{kg}^{-1}$ to $0.936 \mu \mathrm{g} \mathrm{kg}^{-1}$.

For quality assurance/quality control (QA/QC) procedures, blank extractions were done and replicate analysis was performed for all samples for $\mathrm{Hg}$ and PAH. For oyster analysis, in order to ensure enough weight for analysis, composite samples with two or three organisms were analyzed. Percent deviation between replicates was always below 5\%. Also, percent recoveries were analyzed. Recovery was calculated by spiking some of the samples with known concentrations of the specific standard solutions. Method recoveries were evaluated by analysis of the certified sediment NIST-1944 (New York/New Jersey Waterways) and tissue NIST-2974a ("Organics in Freeze-Dried Mussel Tissue"). Recoveries were 


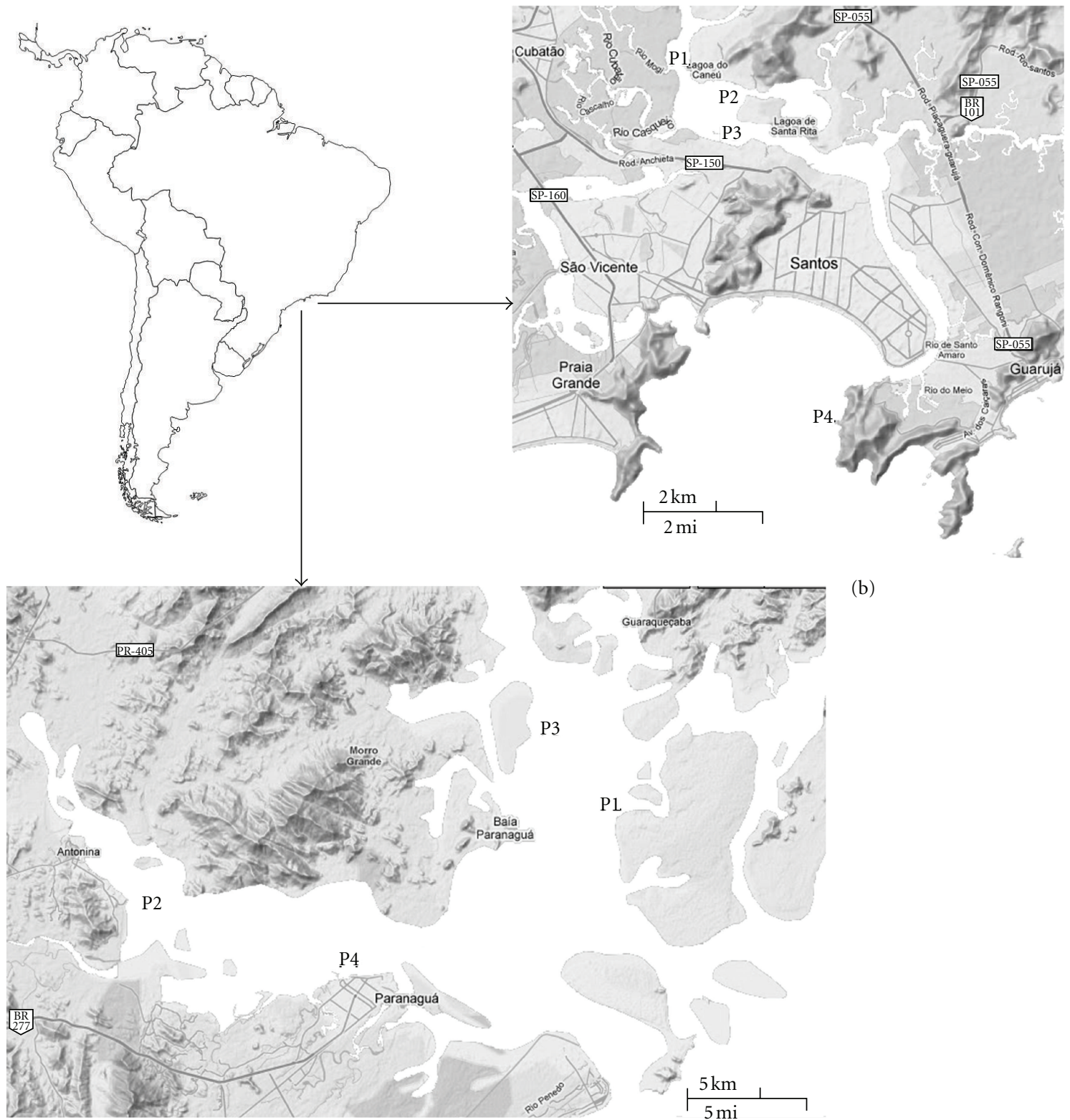

(a)

Figure 1: Distribution of sampling sites in (a) Paranaguá Estuarine System (PES-25 $16^{\prime} \mathrm{S}-25^{\circ} 34^{\prime} \mathrm{S}$; $48^{\circ} 17^{\prime} \mathrm{W}-48^{\circ} 42^{\prime} \mathrm{W}$ ): P1-Guapicú; P2Porto de Antonina; P3-Gamelas; P4-Porto de Paranaguá and B) Santos Estuarine System (SES-23 ${ }^{\circ} 45^{\prime} \mathrm{S}-24^{\circ} 5^{\prime} \mathrm{S}$; $46^{\circ} 15^{\prime} \mathrm{W}-46^{\circ} 30^{\prime} \mathrm{W}$ ): P1Piaçaguera; P2-Bagres Island; P3-Alamoa; P4-Palmas Island.

of $115 \%$ for $\mathrm{Hg}$ and varied from $68.3 \%$ to $118.8 \%$ for PAH. All the glasswares were washed with Extran by Merck, rinsed in acetone and methanol PA (Merck or Synth), and oven-dried at $105^{\circ} \mathrm{C}$ for POP analysis and also set in $20 \%$ nitric acid bath for $\mathrm{Hg}$ analysis. All the reagents used for extractions were HPLC grade and supplied by Baker, Merck, or Mallinckrodt.

Chemical results were compared with their respective controls using Student's $t$-test applied to compare chemical composition and comparisons of these contaminants in the study site. Data of both estuaries were analyzed separately by multivariate analyses, that is, principal component analysis (PCA) for pattern recognition. These analyses were done by the use of the program PAST 2.03 from the University of Oslo.

\section{Results and Discussion}

Table 1 presents a synthesis of all results acquired in this project. Even though two different seasons were assessed, results are presented as simple means of the values obtained because these values were significantly equal when compared 
TABLE 1: Concentration of mercury and PAH in sediments and oysters from Santos and Paranaguá estuarine systems (mean of dry seasonaugust 2008_ and rainy season—may 2009).

\begin{tabular}{|c|c|c|c|c|}
\hline Local/matrix & Total Hg $\left(\mathrm{mg} \mathrm{kg}^{-1}\right)$ & Bioaccumulation $* \%$ & Total PAH $\left(\mu \mathrm{g} \mathrm{kg}^{-1}\right)$ & Bioaccumulation $* \%$ \\
\hline \multicolumn{5}{|c|}{ Sediments-Paranaguá } \\
\hline P1 Guapicú & 0.09 & - & 10.01 & - \\
\hline P2 Antonina Port & 0.11 & - & 9.59 & - \\
\hline P3 Gamelas & 0.13 & - & 16.43 & - \\
\hline P4 Paranaguá Port & 0.15 & - & 21.18 & - \\
\hline \multicolumn{5}{|c|}{ Sediments-Santos } \\
\hline P1 Piaçaguera Channel & 1.92 & - & $1.406,13$ & - \\
\hline P2 Bagres Island & 1.97 & - & 431.71 & - \\
\hline P3 Alemoa & 1.60 & - & 133.72 & - \\
\hline P4 Palmas Island & 0.36 & - & 36.48 & - \\
\hline \multicolumn{5}{|c|}{ Native oysters-Paranaguá } \\
\hline P1 Guapicú & 0.35 & - & 32.20 & - \\
\hline P2 Antonina Port & 0.22 & - & 31.42 & - \\
\hline P3 Gamelas & 0.14 & - & 34.69 & - \\
\hline P4 Paranaguá Port & NA & - & NA & - \\
\hline \multicolumn{5}{|c|}{ Native oysters-Santos } \\
\hline P1 Piaçaguera Channel & NA & - & NA & - \\
\hline P2 Bagres Island & 0.32 & - & 182.99 & - \\
\hline P3 Alemoa & 0.37 & - & 121.18 & - \\
\hline P4 Palmas Island & 0.32 & 一 & 51.72 & - \\
\hline \multicolumn{5}{|c|}{ Caged oysters } \\
\hline Control oyster (T-zero) & 0.08 & - & 32.52 & - \\
\hline \multicolumn{5}{|c|}{ Transplanted oysters, after 30 d-Paranaguá } \\
\hline P1 Guapicú & 0.07 & -18.9 & 42.18 & 29.7 \\
\hline P2 Antonina Port & 0.09 & 10.7 & 35.83 & 10.2 \\
\hline P3 Gamelas & 0.08 & 3.1 & 33.41 & 2.7 \\
\hline P4 Paranaguá Port & 0.03 & -66.0 & 53.70 & 65.2 \\
\hline \multicolumn{5}{|c|}{ Transplanted oysters, after $30 \mathrm{~d}$-Santos } \\
\hline P1 Piaçaguera Channel & 0.12 & 44.0 & 584.33 & 1.697 .0 \\
\hline P2 Bagres Island & 0.20 & 150.9 & 234.32 & 620.6 \\
\hline P3 Alemoa & 0.15 & 86.2 & 295.31 & 808.2 \\
\hline P4 Palmas Island & 0.08 & 0.6 & 50.54 & 55.4 \\
\hline
\end{tabular}

* Caged oysters percent biaccumulation in the 30 day experiment. NA: Not available.

to each other and when Student's $t$-test was applied. The analysis of the sediments has shown that SES is more contaminated by $\mathrm{Hg}$ and PAH than PES. Assessment of contaminants in the sediments of PES, the highest $\mathrm{Hg}$ concentration, was in the port area P4 which violated the SQG (sediment quality guideline) and ERL (effect range low) which is of $0.15 \mathrm{mg} \mathrm{kg}^{-1}$ [15]. Conceptually, the ERL is the 10th percentile of a series of data of ascending levels of contaminants and their related toxicity effects. This guideline is also present in the Brazilian Resolution CONAMA 344/04 as Level 1; such resolution regards the chemical composition of sediments to be dredged and disposed in jurisdictional Brazilian waters, and Level 1 is a threshold effect level, that is, the lowest level, below which adverse effects rarely occur [22-24].

Observing the results of sediments from SES, it was possible to see that sediments from the inner portions of the estuary (Piaçaguera, Bagres Island, and Alemoa Terminal) presented levels of $\mathrm{Hg}$ much above the SQG that is called ERM (Effect Range Medium) which is of $0.72 \mathrm{mg} \mathrm{kg}^{-1}$ and it is the 50th percentile (medium) of a series of data of ascending levels of contaminants and their related toxicity effects [15]. This is representative of concentrations above which toxic effects to the benthic communities frequently occur. It is also related in the above mentioned CONAMA resolution 344/04 as Level 2 and if this sediment was to be dredged, special care must be assigned to handling and disposal of this material. Only sediments from P4 (das Palmas Island) had concentrations below ERM, but still above ERL. This point is very close to an old disposal site for the dredging activities that took place in Santos in the past [16] and also suffers influence from the port area, especially when dredging activities take place. This site is influenced 


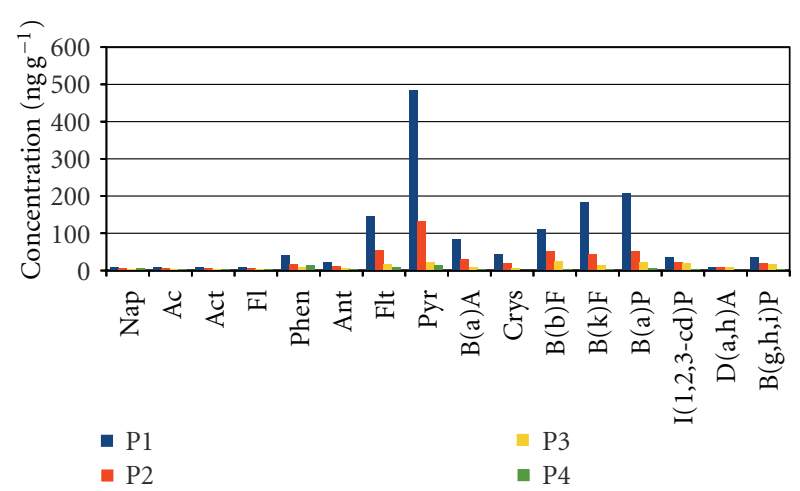

FIgURe 2: Distribution of individual PAHs in sediments from SES. Nap — naphthalene, Ac-acenaphthylene, Act—acenaphthene, Fl— fluorene, Phen-phenanthrene, Ant-anthracene, Flt-fluoranthene, Pyr-pyrene, B(a)a-benzo[a]anthracene, Crys-chrysene, $\mathrm{B}(\mathrm{b}) \mathrm{F}$-benzo[b]fluoranthene, $\mathrm{B}(\mathrm{k}) \mathrm{F}$-benzo[k]fluoranthene, $\mathrm{B}(\mathrm{a}) \mathrm{P}$-benzo[a]pyrene, $\mathrm{I}(1,2,3$-cd) $\mathrm{P}$-indeno[1,2,3-cd] pyrene, $\mathrm{D}$ (a,h)A—dibenzo[a,h] anthracene, and $\mathrm{B}(\mathrm{g}, \mathrm{h}, \mathrm{i}) \mathrm{P}$ - benzo[ghi]perylene.

also by the underwater sewage effluent from the city of Santos that is dumped in the bay and carried to das Palmas Island by weather currents from the SW during storm events [17].

With respect to the PAH, PES has shown very low concentrations in the sediments and little difference among sampling sites. According to ERL/ERM sediment quality values, no harm to the sediment organisms would be caused by the PAH in PES. On the other hand, in SES, violation of ERL for several individual PAHs (known to be responsible for causing cancer in humans [20]) such as pyrene, benzo(a)anthracene, and benzo(a)pirene are not difficult to occur $[12,13,15,17]$. It is possible to note that there is a gradient of contamination that is higher in the inner part of Santos estuary, a fact that was observed in previous studies such as [25-27]. Historically, SES has presented high concentration of metals and hydrocarbons due to the industrial complexity of Cubatão, which includes a petroleum refinery plant and several fertilizers and chemical companies and due to the port area of Santos $[12,16,17,25$, 26]. Figure 2 shows the distribution of individual PAHs in sediments of SES.

Assessing the native oysters collected from these two estuaries, it is noteworthy that in the two most contaminated points (Paranaguá Port in PES-P4-and Piaçaguera Channel in SES-P1) there were no organisms to be collected. Concentrations of $\mathrm{Hg}$ in soft tissues of collected native oysters were quite homogeneous among sampling stations in both PES and SES. The not so clear correlation between levels of $\mathrm{Hg}$ in sediments and organisms in PES may be a result of the absence of conditions for the efficient mercury methylation as a result, for example, of the inorganic mercury complexation by the organic matter, an interaction that decreases the methylation rate. On the other hand, even if methylated, the formed methylmercury can be complexed with bisulfide, decreasing its bioavailability $[5,28]$. This scenery propitiates a complex context where appropriate conditions

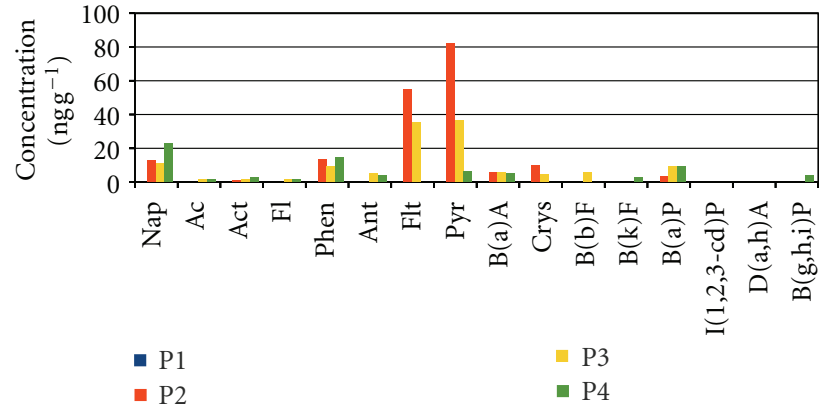

FIgure 3: Distribution of individual PAHs in native oysters in SES. Nap — naphthalene, Ac — acenaphthylene, Act—acenaphthene, Fl— fluorene, Phen-phenanthrene, Ant-anthracene, Flt-fluoranthene, Pyr-pyrene, B(a)a-benzo[a] anthracene, Crys-chrysene, $\mathrm{B}(\mathrm{b}) \mathrm{F}$-benzo[b]fluoranthene, $\mathrm{B}(\mathrm{k}) \mathrm{F}$-benzo[k]fluoranthene, $\mathrm{B}(\mathrm{a}) \mathrm{P}$-benzo[a]pyrene, I(1,2,3-cd)P-indeno[1,2,3-cd]pyrene, D (a,h)A—dibenzo[a,h] anthracene, and $\mathrm{B}(\mathrm{g}, \mathrm{h}, \mathrm{i}) \mathrm{P}$-benzo[ghi]perylene.

for mercury methylation, like organic matter presence, that determines ideal redox conditions for the formation of the organic metallic product and sulfate reducing bacteria activity can, paradoxically, inhibit methylation as a result of the $\mathrm{Hg}^{2+}$ complexation or indirectly be responsible for the complexation of methylmercury by the sulfide species. These aspects of the mercury cycle along with oyster feeding habits, hypothesize reasons that explain why $\mathrm{Hg}$ in sediments either from PES or SES were not completely bioavailable, or, in case it was available, in PES Hg levels in organisms where higher than in the sediments, whereas in SES the levels of $\mathrm{Hg}$ in the sediments were higher than in soft tissues of the native organisms (exception for $\mathrm{P} 4$, where $\mathrm{Hg}$ concentration was very close in the organisms and the sediments).

Similarly to $\mathrm{Hg}$, PAH levels in native oysters from PES were homogeneous along the estuarine system, reinforcing that the levels of PAH in sediments do not pose risk to C. rhizophorae. Levels in sediments were lower than in native organisms for all PES sampling points. In SES, PAH concentration in native organisms varied according to the concentration in sediments; in points $\mathrm{P} 2$ and $\mathrm{P} 3$, but in point $\mathrm{P} 4, \mathrm{PAH}$ levels in the native oysters were higher than in the sediments. These results show a higher concentration of PAH in native oysters from PES and SES compared to the concentration of up to $8.0 \mathrm{mg} \mathrm{kg}^{-1}$ in native oysters from around the world, reported by Neff [5]. Figure 3 presents the distribution of the concentrations of individual PAHs in native oysters of SES.

Comparing these results to those of the experiment with caged oysters, it is possible to observe that the concentrations in native oysters from PES were higher than those of the transplanted organisms for $\mathrm{Hg}$, but almost the same for $\mathrm{PAH}$. The longer exposure period that the native organisms have in relation to the caged organisms explains the higher $\mathrm{Hg}$ concentrations in native oysters comparatively to transplanted organisms. On the other hand, the low levels of PAH in PES sediments did not produce important disparities between the concentration of this contaminant in native and 


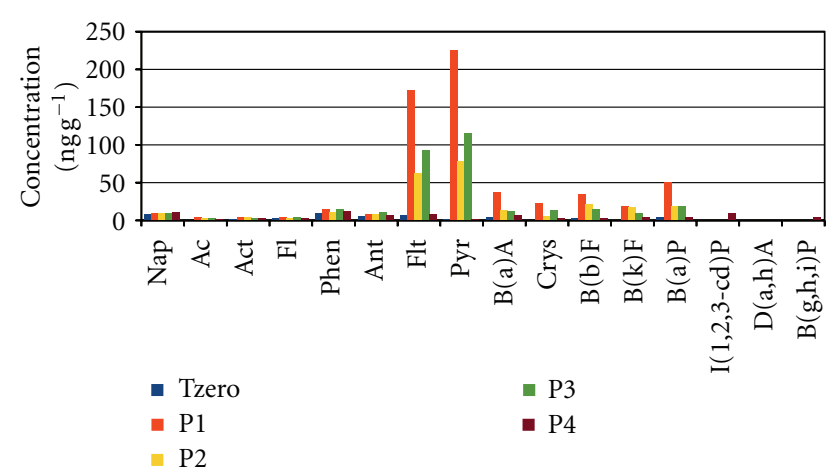

Figure 4: Distribution of individual PAHs in control (T-zero) and transplanted oysters in SES. Nap-naphthalene, Ac-acenaphthylene, Act-acenaphthene, Fl-fluorene, Phen-phenanthrene, Ant-anthracene, Flt-fluoranthene, Pyr-pyrene, B(a)a-benzo [a] anthracene, Crys - chrysene, B(b)F-benzo[b]fluoranthene, B (k)F-benzo[k]fluoranthene, B(a)P-benzo[a]pyrene, I(1,2,3-cd) $\mathrm{P}$-indeno[1,2,3-cd]pyrene, $\mathrm{D}(\mathrm{a}, \mathrm{h}) \mathrm{A}$-dibenzo[a,h] anthracene, and $\mathrm{B}(\mathrm{g}, \mathrm{h}, \mathrm{i}) \mathrm{P}$-benzo[ghi]perylene.

transplanted oysters as did in SES, despite the difference on time of exposure.

When the oyster tissues from the caged experiment were analyzed, a comparison of the results of the transplanted organisms to the results of the control oysters (also called T-zero), it was possible to observe the kinetics of bioaccumulation of these contaminants. In PES, concentration of $\mathrm{Hg}$ and $\mathrm{PAH}$ was quite the same as the control organisms and in some cases even lower. This strongly indicates that contaminants in the sediments of PES may not be bioavailable to the organisms. van Straalen [29] establishes that measurements of chemicals in biological matrices can be used to estimate ecological risk not by total concentration in the environment, but by estimating the bioavailable fraction of these contaminants.

Assessing the data from organisms transplanted to SES and comparing to control organisms, it is possible to observe that concentrations of these contaminants were higher in Piaçaguera (P1), Bagres Island (P2), and Alemoa (P3) and very close to T-zero in Palmas Island (P4). This proves that there is an unquestionable bioavailability of contaminants from sediments to the water column and to the transplanted oysters. Hg has shown from 44 to $150 \%$ increase in concentration, while $\mathrm{PAH}$ reached more than $1,600 \%$ increase in Piaçaguera (P1), more than $600 \%$ in Bagres Island (P2), and more than $800 \%$ in Alemoa (P3). The evaluations of contaminant residues in organisms are real indicators of contaminant bioavailability as have been shown by a number of studies [29]. Figure 4 shows individual PAHs distribution in these transplanted organisms.

It is possible to note a direct relationship in the concentrations of all PAHs, especially fluoranthene, pyrene, benzo(a)anthracene, benzo(b)fluoranthene, benzo(k)fluoranthene, and benzo(a)pyrene from the sediments, native and caged oysters as can be seen in Figures 2, 3, and 4.

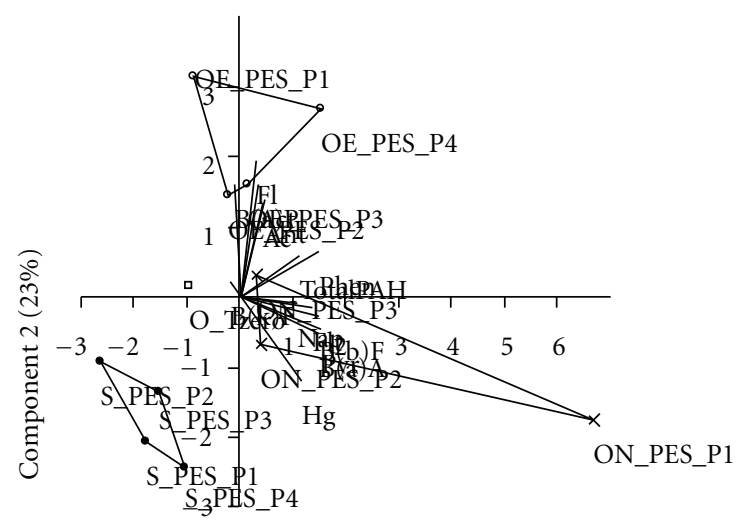

Component $1(49 \%)$

(a)

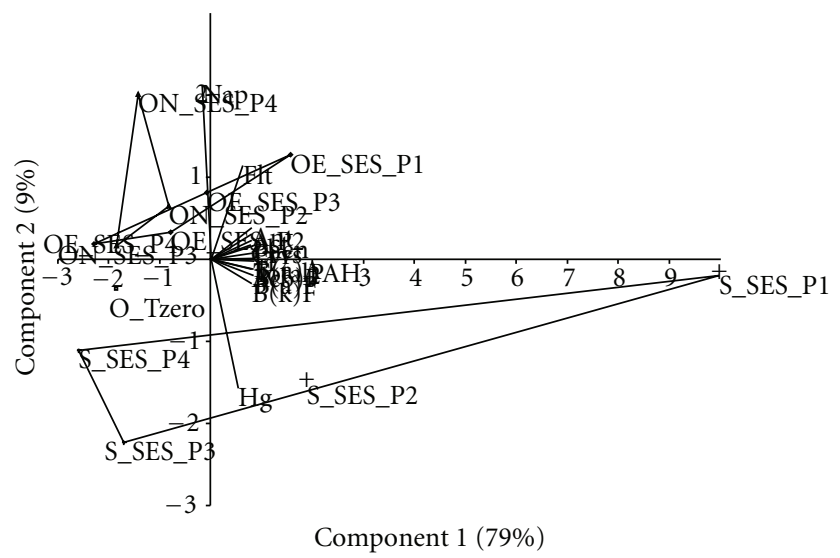

(b)

Figure 5: Principal component analysis of sediments, native oysters, and transplanted oysters. (a) Paranaguá, (b) Santos. OEoyster in Experiment; ON_native oyster; S—sediments; SESSantos Estuarine System; PES-Paranaguá Estuarine System. Nap-naphthalene, Ac-acenaphthylene, Act-acenaphthene, Fl-fluorene, Phen-phenanthrene, Ant-anthracene, Flt-fluoranthene, Pyr-pyrene, B(a)a-benzo[a] anthracene, Crys-chrysene, $\mathrm{B}(\mathrm{b}) \mathrm{F}$ - benzo[b]fluoranthene, $\mathrm{B}(\mathrm{k}) \mathrm{F}$-benzo[k] fluoranthene, $\mathrm{B}(\mathrm{a}) \mathrm{P}$-benzo[a]pyrene, I(1,2,3-cd)P-indeno[1,2,3-cd]pyrene, D (a,h)A—dibenzo[a,h] anthracene, and B(g,h,i)P-benzo[ghi]perylene.

Principal component analysis of the whole data set did not show a clear separation of the groups, but when processed each site alone it shows well-defined groupings of noncontaminated sediments from PES along with a separate group of oysters from the experiment and other groups of native oysters (Figure 5(a)) (groupings are presented as polygons, which represent the compartments-sediments, native oysters, and transplanted oysters). The first two components account for $72 \%$ of the significance, but they are very close to each other.

Analyzing the PCA for SES (Figure 5(b)), the first principal component represents $79 \%$ of the data and the second component represents $9 \%$ giving a total of $88 \%$. Vectors 
representing $\mathrm{Hg}$, individual $\mathrm{PAHs}$, and total $\mathrm{PAH}$ are mostly projected in principal component 1 with only a small contribution related to component 2 which is mostly represented by $\mathrm{Hg}$ and two low molecular weight individual PAHs (naphthalene and fluoranthene). Contaminated sediments from SES are clearly separated from the organisms and sediments from Piaçaguera (P1) and Ilha dos Bagres (P2) which are in a different part of the PCA. Oysters grouping did not show a clear distinction between native and caged oysters except for the oysters transplanted to Piaçaguera (P1) and the native oysters from das Palmas Island (P4). It is possible to observe almost the same pattern in the sediments and caged oysters pointing to pyrogenic $\mathrm{PAH}$ of high molecular weight probably desorbed from the sediments from P1. Native oysters from P4 show some accumulation of some petrogenic low molecular weight individual PAHs present in this place as oil and gasoline spills from small cruise and fishing boats in the marina from the fisherman's club present in the island.

\section{Conclusions}

The aim of this study was to assess sediment quality and bioavailability of contaminants in the estuarine systems of Santos and Paranaguá in southeastern Brazil. Chemical analysis has shown that sediments and native oysters in PES are not significantly impacted, while in the inner part of SES it presented high concentrations of $\mathrm{Hg}$ and $\mathrm{PAH}$. Also, the most contaminated sites have shown an absence of native organisms, while caged oysters presented varying levels of bioaccumulation.

From an overall evaluation of these results, it is possible to conclude that the use of transplanted oysters is a wonderful tool not only for bioaccumulation studies, but also for discriminating sites with different levels of contamination. Also, caged oysters, in this case Crassostrea rhizophorae, proved to be good indicating organisms for bioavailability and monitoring programs since they bioaccumulated significant amounts of contaminants in Santos estuary.

\section{Acknowledgments}

The authors would like to thank Brazilian Education Ministry-Coordenação de Aperfeiçoamento de Pessoal e Ensino Superior (CAPES no. 099/06) and Spanish Education Ministry-Ministerio de Educación-Dirección General de Universidades (MECD/DGU no. PHB2005-0100-PC) for the International Cooperation Program Brazil-Spain in financing this study.

\section{References}

[1] M. K. Hill, Understanding Environmental Pollution, Cambridge University Press, 3rd edition, 2010.

[2] United States Environmental Protection Agency, "Bioaccumulation testing and interpretation for the purpose of sediment quality assessment. Status and needs," Office of Water (4305). Office of Solid Waste (5307W). EPA-823-R-00-001. p. 111, 2000.
[3] National Research Council, Bioavailability of Contaminants in Soils and Sediments: Processes, Tools, and Applications, National Academies Press, 2003.

[4] C. J. Leeuwen and T. G. Vermeire, Risk Assessment of Chemicals: An Introduction, Springer, Dordrecht, The Netherlands, 2nd edition, 2007.

[5] J. M. Neff, Bioaccumulation in Marine Organisms. Effect of Contaminants From Oil Well Produced Water, Elsevier, Amsterdam, The Netherlands, 2002.

[6] E. Cortazar, L. Bartolomé, S. Arrasate et al., "Distribution and bioaccumulation of PAHs in the UNESCO protected natural reserve of Urdaibai, Bay of Biscay," Chemosphere, vol. 72, no. 10, pp. 1467-1474, 2008.

[7] International Mussel Watch, Initial Implementation Phase. Draft Final Report, National Oceanic and Atmospheric Administration, 1993.

[8] M. C. R. Amaral, M. F. Rebelo, J. P. M. Torres, and W. C. Pfeiffer, "Bioaccumulation and depuration of $\mathrm{Zn}$ and $\mathrm{Cd}$ in mangrove oysters (Crassostrea rhizophorae, Guilding, 1828) transplanted to and from a contaminated tropical coastal lagoon," Marine Environmental Research, vol. 59, no. 4, pp. 277-285, 2005.

[9] M. Costa, E. Paiva, and I. Moreira, "Total mercury in Perna perna mussels from Guanabara Bay-10 years later," Science of the Total Environment, vol. 261, no. 1-3, pp. 69-73, 2000.

[10] M. F. Rebelo, M. C. R. Amaral, and W. C. Pfeiffer, "High Zn and $\mathrm{Cd}$ accumulation in the oyster Crassostrea rhizophorae, and its relevance as a sentinel species," Marine Pollution Bulletin, vol. 46, no. 10, pp. 1354-1358, 2003.

[11] C. A. R. Silva, B. D. Smith, and P. S. Rainbow, "Comparative biomonitors of coastal trace metal contamination in tropical South America (N. Brazil)," Marine Environmental Research, vol. 61, no. 4, pp. 439-455, 2006.

[12] D. M. S. Abessa, R. S. Carr, E. C. P. M. Sousa et al., "Integrative ecotoxicological assessment of a complex tropical estuarine system," in Marine Pollution: New Research, Nova Science, New York, NY, USA, 2008.

[13] R. B. Choueri, A. Cesar, D. M. S. Abessa et al., "Development of site-specific sediment quality guidelines for North and South Atlantic littoral zones: comparison against national and international sediment quality benchmarks," Journal of Hazardous Materials, vol. 170, no. 1, pp. 320-331, 2009.

[14] R. B. Choueri, A. Cesar, R. J. Torres et al., "Integrated sediment quality assessment in Paranaguá Estuarine System, Southern Brazil," Ecotoxicology and Environmental Safety, vol. 72, no. 7, pp. 1824-1831, 2009.

[15] R. J. Torres, D. M. S. Abessa, F. C. Santos et al., "Effects of dredging operations on sediment quality: contaminant mobilization in dredged sediments from the Port of Santos, SP, Brazil," Journal of Soils and Sediments, vol. 9, no. 5, pp. 420432, 2009 .

[16] M. L. Lamparelli, M. P. Costa, V. A. Prósperi et al., Sistema Estuarino de Santos e São Vicente, Relatório Técnico CETESB, São Paulo, Brazil, 2001.

[17] D. M. S. Abessa, R. S. Carr, B. R. F. Rachid, E. C. P. M. Sousa, M. A. Hortelani, and J. E. Sarkis, "Influence of a Brazilian sewage outfall on the toxicity and contamination of adjacent sediments," Marine Pollution Bulletin, vol. 50, no. 8, pp. 875885, 2005.

[18] A. Cesar, C. D. S. Pereira, A. R. Santos et al., "Ecotoxicology assessment of sediments from Santos and Sao Vicente Estuarine," System Brazilian Journal of Oceanography, vol. 54, no. 1, pp. 55-63, 2006. 
[19] United States Environmental Protection Agency, "A compendium of chemical, physical and biological methods for assessing and monitoring the remediation of contaminated sediment sites," No. 68-W-99-033, p. 291, 2003.

[20] United States Environmental Protection Agency, "Procedures for the derivation of equilibrium partitioning sediment benchmarks (ESBs) for the protection of benthic organisms: $\mathrm{PAH}$ Mixtures," EPA-822-R-02-013, p. 175, 2003.

[21] United States Environmental Protection Agency, Test Methods For Evaluating Solid Waste (SW-846), US Environmental Protection Agency, Office of Solid Waste, Economic, Methods, and Risk Analysis Division, 1996.

[22] United States Army Corps of Engineers, "Use of sediment quality guidelines (SQGs) in dredged material management," Dredging Research Technical Note EEDP-04-29, p. 14, 1998.

[23] S. L. Simpson, G. E. Batley, A. A. Chariton et al., Handbook for Sediment Quality Assessment, CSIRO Publishing, Bangor, Australia, 2006.

[24] R. J. Wenning, G. E. Batley, C. G. Ingersoll, and D. W. Moore, Use of Sediment Quality Guidelines and Related Tools for the Assessment of Contaminated Sediments, Society of Environmental Toxicology and Chemistry, 2005.

[25] P. M. Medeiros and M. Caruso Bícego, "Investigation of natural and anthropogenic hydrocarbon inputs in sediments using geochemical markers. I. Santos, SP-Brazil," Marine Pollution Bulletin, vol. 49, no. 9-10, pp. 761-769, 2004.

[26] C. C. Martins, M. C. Bicego, and R. C. Montone, "Hidrocarbonetos marcadores geoquímicos em testemunhos de sedimentos do sistema estuarino de Santos e São Vicente, SP," in Proceedings of the 28a Reunião Anual da Sociedade Brasileira de Química, Poços de Caldas, Brazil, 2005.

[27] A. A. Mozeto, R. J. Torres, F. C. Santos, M. DelGrande, D. M. S. Abessa, and M. R. L. Nascimento, "Effects of dredging activities on contaminated sediment quality: contaminant mobilization in dredging sediments of the Port of Santos, SP, Brazil," in Proceedings of the 17th SETAC Europe Annual Meeting, p. 72, Porto, Portugal, May 2007.

[28] N. M. Lawson and R. P. Mason, "Accumulation of mercury in estuarine food chains," Biogeochemistry, vol. 40, no. 2-3, pp. 235-247, 1998.

[29] N. M. van Straalen, "Chapter 18 Contaminant concentrations in organisms as indicators of bioavailability: a review of kinetic theory and the use of target species in biomonitoring," Developments in Soil Science, vol. 32, pp. 449-477, 2008. 

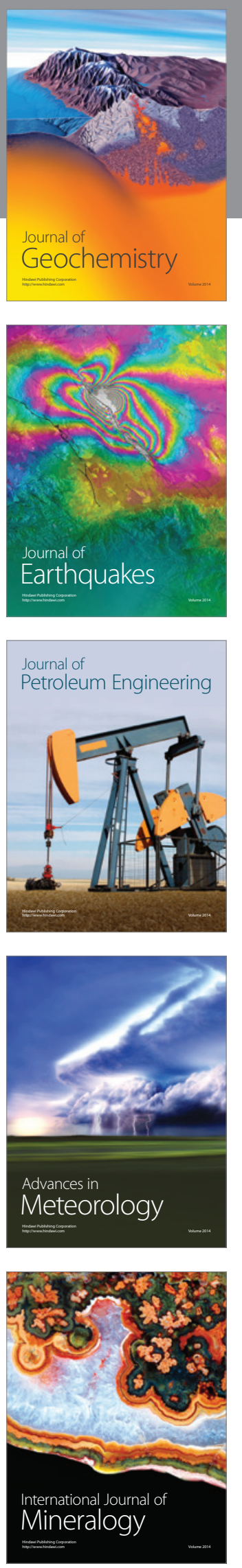
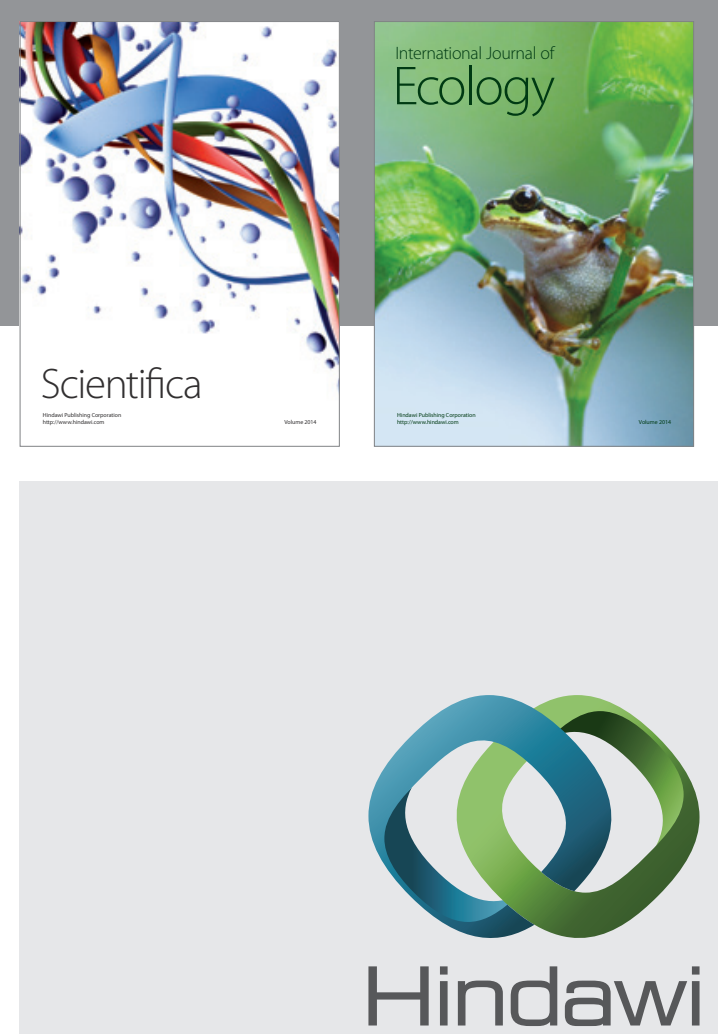

Submit your manuscripts at http://www.hindawi.com
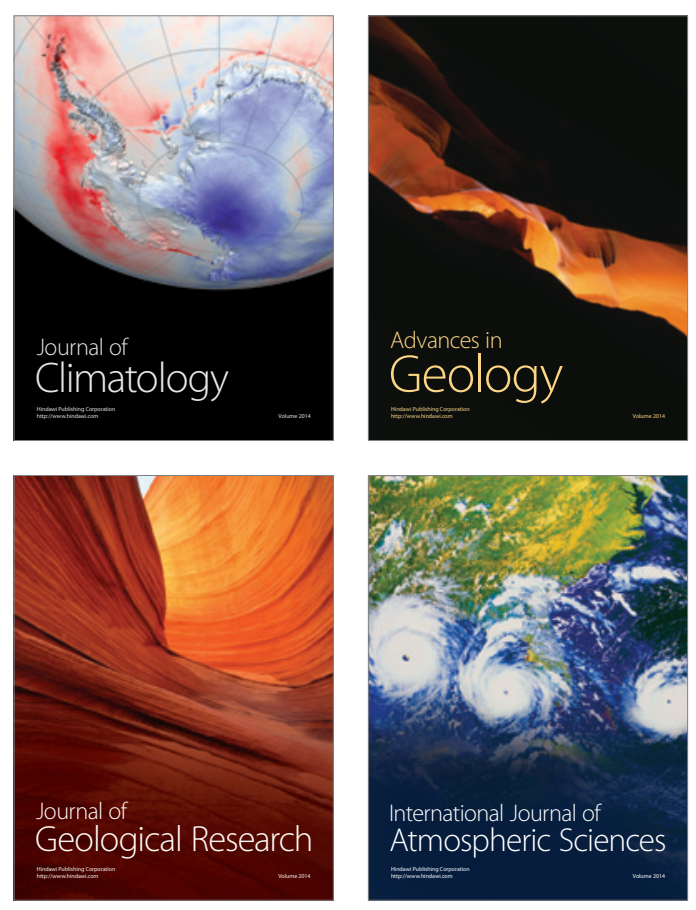
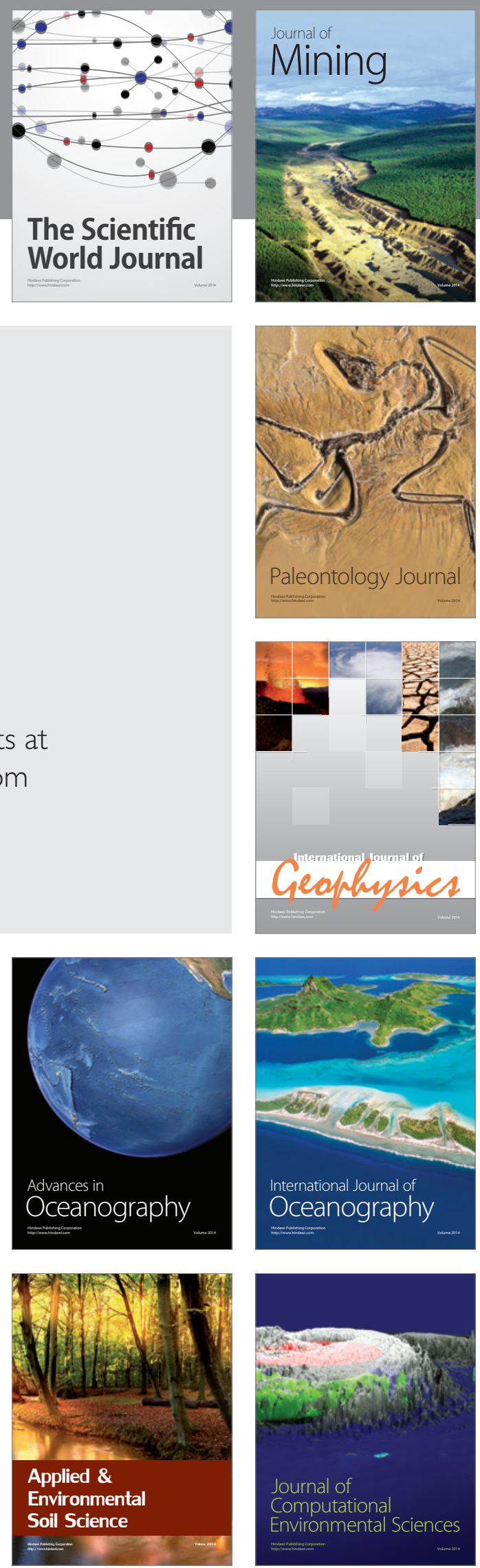